\title{
Life History of Tendaguru Sauropods as Inferred from Long Bone Histology
}

\author{
P. Martin Sander ${ }^{1}$
}

With 4 figures

\begin{abstract}
Sauropod dinosaurs present exceptional challenges in understanding their biology because of their exceptional body size. One of these, life history, can be inferred from the histology of their bones. For this purpose, the diverse sauropod assemblage of the Upper Jurassic Tendaguru beds was sampled with a new coring method which provided unprecented access to and insights into sauropod bone histology.

Growth series of humeri and femora as well as long growth records from single bones suggest that all four sauropod taxa are characterized by continued growth after sexual maturity but that growth was determinate. Fibrolamellar bone is dominant in the samples, indicating that the bones of the Tendaguru sauropods grew at rates comparable to those of modern large mammals. The growth pattern of these sauropods thus combines typically reptilian traits with typically mammalian traits. In the details of their bone histology, the Tendaguru sauropod taxa show considerable variation which reflects life history. In addition, Barosaurus exhibits probable sexual dimorphism in bone histology.
\end{abstract}

Key words: Jurassic, Dinosauria, Sauropoda, Tendaguru, bone histology, life history.

\section{Zusammenfassung}

Das Verständnis der Biologie der sauropoden Dinosaurier wird durch ihre enorme Körpergröße außerordentlich erschwert. Allerdings kann ein Aspekt, die Lebensgeschichte, anhand der Histologie ihrer Knochen untersucht werden. Zu diesem Zweck wurde die diverse Sauropoden-Vergesellschaftung der oberjurassischen Tendaguru-Schichten beprobt, und zwar mit einer neuartigen Kernbohrmethode, die einen herausragenden Zugang und Einblick in die Knochenhistologie der Sauropoden ermöglichte.

Wachstumsserien von Humeri und Femora sowie umfassende Überlieferungen des Wachstums von Individuen anhand einzelner Knochen machen es wahrscheinlich, daß alle vier Sauropoden-Taxa der Tendaguru-Schichten durch ein auch nach der Geschlechtsreife anhaltendes Wachstum gekennzeichnet waren. Allerdings ging das Wachstum nicht bis zum Tode des Tieres weiter, sondern kam bei einer etwas variablen Maximalgröße zum Stillstand.

Fibrolamellärer Knochen ist der vorherrschende Knochentyp in den Proben, was anzeigt, daß die Tendaguru-Sauropoden mit für Säugetieren typische Raten wuchsen. Die Tendaguru-Sauropoden kombinerten also ein für Reptilien typisches Muster des Wachstums, nämlich nach der Geschlechtsreife anhaltendes Wachstum, mit für Säuger typischen Raten des Wachstums. Die verschiedenen Sauropoden-Taxa zeigen erstaunliche Unterschiede in den Details ihrer Knochenhistologie, die Unterschiede in der Lebensgeschichte belegen. Bei Barosaurus scheint außerdem ein Geschlechtsdimorphismus in der Histologie der Langknochen vorzukommen.

Schlïsselwörter: Jura, Dinosauria, Sauropoda, Tendaguru, Knochenhistologie, Lebensgeschichte.

\section{Introduction}

The sauropod assemblage of the Tendaguru beds of Tanzania is only second in diversity and number of finds to that of the Morrison Formation of the Western Interior of the USA. Both assemblages are Late to latest Jurassic in age and show certain similarities despite their great geographic separation. Two of the four Tendaguru genera, Brachiosaurus and Barosaurus, are also known from the Morrison while the other two, Dicraeosaurus and Janenschia, have distinctive Gondwanan affinities (McIntosh et al. 1997). Thus, an understanding of the life history of the Tendaguru taxa is of significance for several higher taxa of Upper Jurassic sauropods. Little direct evidence of life history has been available up to date, and almost none derived from paleohistologic work.

Paleohistology, however, is uniquely suited to address life history question in extinct tetrapods,

\footnotetext{
${ }^{1}$ Institut für Paläontologie, Universität Bonn, Nussallee 8, D-53115 Bonn, Germany. e-mail: martin.sander@uni-bonn.de Received February 1999, accepted May 1999
} 
especially in combination with skeletochronology (Ricqlès 1983, Ricqlès et al. 1991, Castanet \& Smirina 1990, Reid 1997, Varricchio 1997). This is because bone tissue preserves the only, albeit partial, record of growth of the individual, even in living tetrapods. Other lines of evidence, such as from tracks and trackways, nesting sites, and taphonomy are indirect and in the case of tracks and nesting sites difficult to assign to specific taxa. It should be kept in mind, though, that the studies of life history in extinct tetrapods, including dinosaurs (Weishampel \& Horner 1994), are still in their infancy, regardless of method. The purpose of the current paper is thus to establish some details of the life history of sauropods using the histology of the long bones of the Tendaguru taxa.

A major disadvantage of the paleohistologic method is its destructive nature because bone samples have to be taken and ground into thin sections. Ideally, bones of the entire skeleton are sampled as well as samples from different locations in a single bone. This obviously is not feasable, especially when more than one individual of a species is to be studied. However, a thorough understanding of the principles of bone growth and remodelling (Francillon-Vieillot et al. 1990, Ricqlès et al. 1991) allows the selection of a small number of precisely defined sample sites that are representative of the growth history of the entire individual. Sauro-

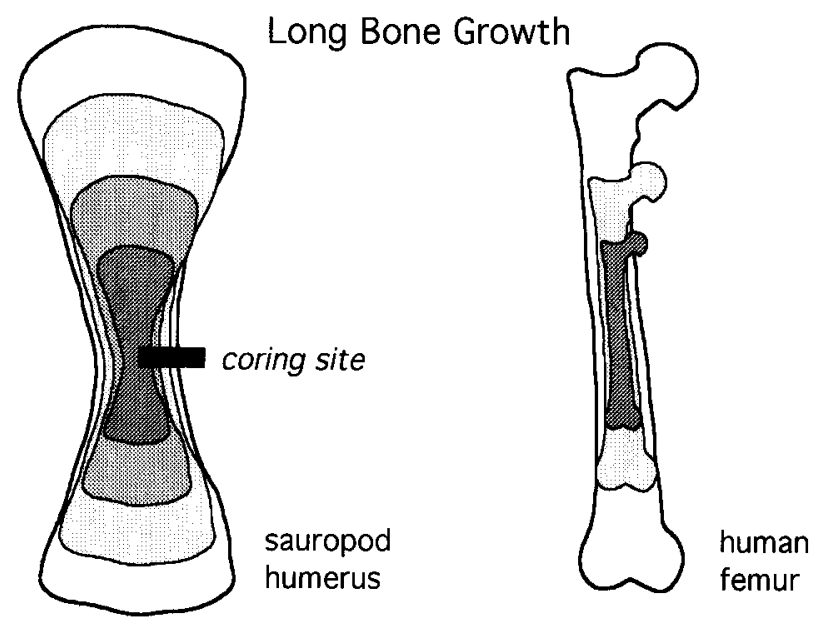

Fig. 1. Schematic representation of long bone growth in tetrapods. Long bone growth in sauropods is purely appositional due to their simple bone shape which makes morphogenesis-related remodelling during growth unnecessary. Bones with complex shapes, however, experience considerable resorption and redeposition during growth as exemplified by the head of the human fermur. In either bone, the middle of the shaft is the most likely site to preserve a long growth record and is thus best suited for sampling, as was done in the sauropod bones. pods represent a most appropriate group in this respect because their long bones can be sampled at a single site, the middle of the shaft. Samples from this site can be argued to be representative for the entire animal. This is because these largest bones in the skeleton had the fastest bone deposition rates, leading to an extended growth record. In addition, because of their simple morphology, sauropod long bones are not affected by remodelling due to morphogenetic constraints, and consequently long bone growth is largely appositional. This means that the bone of the juvenile is potentially contained within the bone of the adult (Fig. 1). A question not solvable on general principles, however, is that of the degree of remodelling of the

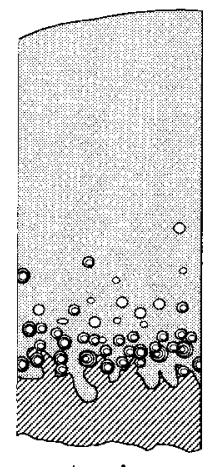

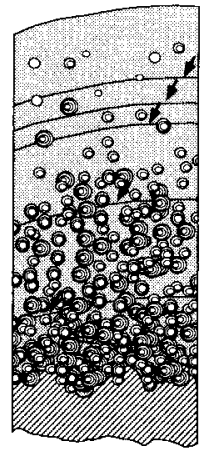

type B

Barosaurus

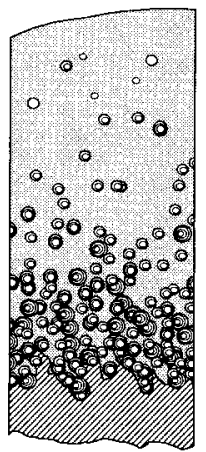

Brachiosaurus
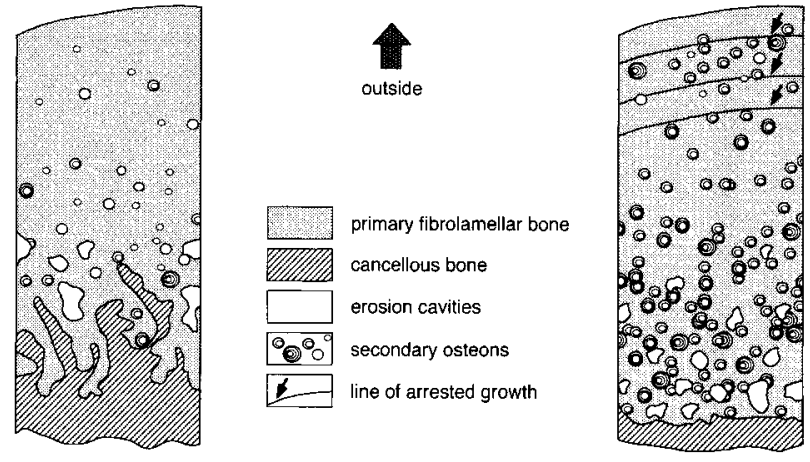

Janenschia

Dicraeosaurus

Fig. 2. Schematic comparison of bone histology of all four Tendaguru sauropod genera. Barosaurus shows two different histologic types: type $\mathrm{A}$ is characterized by continuous deposition of fibrolamellar bone and only few secondary osteons, whereas in type B numerous LAGs are found throughout the cortex as well as many secondary osteons. Barosaurus in general is characterized by an abrupt transition from cancellous bone of the medullary region to compact bone. In comparison, that of Brachiosaurus is more gradual. This genus also differs from Barosaurus type A and Dicraeosaurus in the considerable number of secondary osteons, especially in large individuals. Dicraeosaurus is characterized by erosion cavities throughout the cortex and a very gradual transition between cancellous bone and compact bone. Janenschia shows many erosion spaces in the inner cortex, secondary osteons throughout the cortex, and LAGs in the outer cortex. 
Table 1

Sauropod long bones sampled for this study. These represent only a fraction of the known material. All specimens are from the Tendaguru beds (Upper Jurassic, Tanzania) and are housed in the collections of the Museum für Naturkunde der Humboldt-Universität zu Berlin, Germany. MSM = Middle Saurian Marls, USM = Upper Saurian Marls. Abbreviations for individual age: $\mathbf{j}=$ juvenile, $\mathrm{a}=$ adult, $\mathrm{o}=$ post-growth

\begin{tabular}{|c|c|c|c|c|c|c|c|}
\hline Genus & Spec. \# & bone & side & length $(\mathrm{cm})$ & bed & remarks & indiv. age \\
\hline Brachiosaurus & XX 19 & humerus & 1 & 69 & MSM & & $\mathrm{j}$ \\
\hline Brachiosaurus & $\operatorname{cc} 2$ & humerus & $\mathrm{r}$ & 108 & USM & & a \\
\hline Brachiosaurus & T 8 & humerus & 1 & 128 & USM & & a \\
\hline Brachiosaurus & $t 7$ & humerus & $\mathrm{r}$ & 153 & MSM & & $\mathrm{a}$ \\
\hline Brachiosaurus & J 12 & humerus & $\mathrm{r}$ & 170 & USM & & $\mathrm{a}$ \\
\hline Brachiosaurus & II $28 \mathrm{e}$ & humerus & l & 176 & USM & & a \\
\hline Brachiosaurus & MB.R.1990.1 & ulna & 1 & 90 & $?$ & & $\mathrm{a}$ \\
\hline Brachiosaurus & St 134 & femur & $\mathrm{r}$ & 74 & MSM & & $\ddot{j}$ \\
\hline Brachiosaurus & IX 1 & femur & 1 & 88 & USM & & $\mathrm{a}$ \\
\hline Brachiosaurus & dd 452 & femur & 1 & 135 & MSM & & $\mathrm{a}$ \\
\hline Brachiosaurus & Nr. 305 & femur & $\mathrm{r}$ & 156 & $?$ & & a \\
\hline Brachiosaurus & St 291 & femur & $\mathrm{r}$ & 183 & MSM & & o \\
\hline Brachiosaurus & $X V$ & femur & 1 & 219 & USM & & a \\
\hline Brachiosaurus & No 85 & tibia & $?$ & 85 & USM & & $\mathrm{a}$ \\
\hline Barosaurus & G 91 & humerus & $\mathrm{r}$ & 43.5 & USM & type A & $\mathrm{j}$ \\
\hline Barosaurus & MB.R.2625 & humerus & 1 & 61 & $?$ & type B & $\mathrm{a}$ \\
\hline Barosaurus & IX 94 & humerus & 1 & 64 & USM & type A & $\mathrm{j}$ \\
\hline Barosaurus & XVI 641 & humerus & 1 & 73 & USM & type A & $\mathrm{a}$ \\
\hline Barosaurus & $\mathrm{XI}$ a7 & humerus & l & 80.5 & USM & type A & $\mathrm{a}$ \\
\hline Barosaurus & $\mathrm{A} 1$ & humerus & $\mathrm{r}$ & 99 & USM & type A & a \\
\hline Barosaurus & $\mathrm{Ki} 71 \mathrm{a}$ & femur & 1 & 102 & MSM & type A & a \\
\hline Barosaurus & Ki 2 & femur & $r$ & 119 & MSM & type B & a \\
\hline Barosaurus & NW 4 & femur & 1 & 135 & $?$ & type A & o \\
\hline Barosaurus & Ki 5 & tibia & $r$ & 84 & MSM & type B & a \\
\hline Barosaurus & H 5 & fibula & $?$ & 96 & USM & type A & $\mathrm{a}$ \\
\hline Dicraeosaurus & ab 10 & humerus & 1 & 58 & USM & D. sattleri & a \\
\hline Dicraeosaurus & O 3 & humerus & $\mathrm{r}$ & 61 & USM & D. sattleri & $\mathrm{a}$ \\
\hline Dicraeosaurus & $a b 2$ & humerus & $\mathrm{r}$ & 62 & USM & D. sattleri & a \\
\hline Dicraeosaurus & O 2 & femur & $\mathrm{r}$ & 98 & USM & D. sattleri & $\mathrm{a}$ \\
\hline Dicraeosaurus & dd 3032 & femur & $\mathrm{r}$ & 114 & MSM & D. hansemanni & o \\
\hline Janenschia & Nr. 22 & femur & 1 & 127 & $?$ & & o \\
\hline
\end{tabular}

cortex independent of morphogenesis, i.e. resorption from the medullary region and Haversian substitution, leading to a partial or complete destruction of earlier ontogenetic stages. As will be demonstrated below, however, most of the bones investigated showed remarkably little evidence of remodelling (Fig. 2).

The suitability of long bones for studying life history fortunately coincides with the predominance of long bones in the sauropod assemblage from the Tendaguru beds. In addition, the two more common taxa, Brachiosaurus and Barosaurus, are represented by entire growth series of long bones (Table 1). Through the generosity and open mindedness of the curators of the collections at the Museum für Naturkunde der Humboldt-Universität zu Berlin, which holds by far the largest collection of Tendaguru dinosaurs, it was possible to acquire a representative histologic sample of the sauropod long bones from this assemblage.

\section{Samples and methods}

Bones sampled in this study were primarily humeri and femora as well as a few bones of the lower limb (Table 1). The assignment to taxon followed Janensch (1961) or, in case of specimens not mentioned in this work, the specimen labels which are based on identifications of Janensch. More recent authoritative identifications are not available, and identifications of bones based on microstructure during the course of this study show remarkable agreement with the labels of Janensch. Bones to be sampled were selected on the base of size and preservation. The preservation requirement was that the bone was sufficiently complete for accurate taxonomic identification and size determination and that the mid-shaft region was well preserved without major cracks or plaster reconstructions. If possible, the smallest and the largest bones known were sampled.

A novel sampling method was employed to minimize destruction: small $(14 \mathrm{~mm} \varnothing)$ cores of the entire cortex (up to $60 \mathrm{~mm}$ in thickness) were drilled with a diamond-studded coring bit. This method also allows for very precise sample site location which is crucial if the samples are to be representative for the entire bone and growth history of the animal, and are to be compared among each other (Fig. 1).

The cores were cut longitudinally in the plane perpendicular to the bone long axis, and a thin section was ground from one of the halves. The other cut surface was finely ground 
and polished to a high gloss to facilitate study in incident light. The thin section and polished section thus represent part of a cross section of the entire bone at mid-shaft where the cortex is thickest. The sections were studied using the standard light microscopic techniques. Terminology largely follows Francillon-Vieillot et al. (1990).

\section{Results}

\section{Taxon-dependent growth histories}

The Tendaguru sauropods show remarkable differences in bone histology between taxa (Fig. 2), and each will be discussed individually. Although humerus and femur samples of one taxon usually differ somewhat in details of their histology, they are sufficiently similar to be discussed together. Not enough lower limb bone samples were taken for a meaningful comparison, but their histology offers nothing to contradict the conclusions reached from the upper limb bones. In addition, although there are clear indications that the ontogenetic stage of a bone is closely correlated with bone size (see below), the taxonomic differences are common to bones of all sizes.

As noted in other sauropods by earlier workers (Ricqlès 1968, 1983, Rimblot-Baly et al. 1995, Reid 1981, 1990), primary fibrolamellar bone is the dominant tissue type in all Tendaguru sauropods. Differences between taxa are found in details of fibrolamellar bone histology but mainly in the nature and degree of bone remodelling. This includes the number and spacing of secondary osteons, their coagulation to form Haversian bone, and the nature of the transition from the compact bone of the cortex to the cancellous bone of the medullary region (Fig. 2). Other differences are found in the nature and spacing of growth lines, two types of which are encountered: Lines of arrested growth (LAGs) and polish lines. Polish lines are subtle growth lines that are only visible to the naked eye or binocular microscope using reflected light on the polished surfaces or in dark field illumination with the compound microscope (Sander submitted).

Yet another type of primary bone, lamellarzonal bone, occurs in all Tendaguru sauropods. In some large specimens of Brachiosaurus, Barosaurus, and Dicraeosaurus as well as in the single Janenschia bone studied, a very thin layer of lamellar-zonal bone terminated bone deposition. In addition to having a much-reduced vascular network, this layer also shows one to several LAGs.
Brachiosaurus (Fig. 2) has a relatively thick cortex of fibrolamellar bone with an increasing amount of secondary osteons in the inner cortex as bone size increases. In the largest individual, the secondary osteons may occur in sufficient density to produce true Haversian bone in this region. Only in these large individuals, isolated secondary osteons extend to the outer region of the cortex. The transition from cortex to cancellous bone is rather abrupt as there seems to be a clearly defined resorption front delimiting the medullary region. Growth lines are rare and, if present, irregularly spaced in all Brachiosaurus specimens studied. In terms of growth history, the thick cortex of fibrolamellar bone and the poor development of growth lines indicate that Brachiosaurus grew at a high rate, almost without interruptions, and for a long time. The relatively abundant secondary osteons may be due to the very large size of the animal, which correlates with a long period of growth. In mammals and other tetrapods where it occurs, Haversian substitution appears to be linked to large sizes as well (Ricqlès et al. 1991). However, it may not be the large size per se that leads to Haversian substitution, but simply the long life span of a given region of primary bone. Haversian substitution thus may occur at a certain base rate without any physiological or biomechanical trigger (de Ricqlès, pers. com. 1998).

Barosaurus is remarkable in that it shows two distinctive types of bone histology (Fig. 2), one of which (type A, 7 specimens) is more than twice as common as the other (type B, 3 specimens). Type A is characterized by a cortex of fibrolamellar bone that, even in large individuals, is surprisingly little affected by Haversian remodelling (Fig. 2). Only the innermost part of the cortex shows some secondary osteons, but those do not coalesce to form Haversian bone. The transition from cortex to cancellous bone of the medullary region is rather abrupt, as seen in Brachiosaurus. LAGs are lacking in Barosaurus type A, only polish lines are present in some specimens. Type B sections (Fig. 2) on the other hand, show numerous and regularly spaced LAGs. As opposed to type $\mathrm{A}$, the cortex is strongly affected by Haversian remodelling. The inner cortex consists of solid Haversian bone while the outer cortex shows numerous secondary osteons, even in small individuals. The two types of bone histology thus record rather different patterns of growth. Type A grew rapidly and without interruptions. Type $B$, on the other hand, grew more slowly and in a cyclical fashion as evidenced by the regularly spaced LAGs. 
Dicraeosaurus is rather similar to Barosaurus type $\mathrm{A}$ in having a cortex composed of fibrolamellar bone with only isolated secondary osteons (Fig. 2). Two differences are apparent, however, that are usually sufficient to identify the taxa in thin sections. First, Dicraeosaurus is characterized by erosion activity that affects the entire cortex. Thus the transition from cancellous bone to cortex is gradual and irregular because erosion embayments extend deeply from the medullary region into the cortex (Fig. 2), and large erosion cavities occur throughout the inner half of the cortex. Erosional activity in the outer cortex is documented by isolated secondary osteons.

The other difference is that in Dicraeosaurus the fibrolamellar bone shows a peculiar cyclical change of vascular architecture, bands of laminar bone alternating with bands of bone dominated by longitudinal vascular canals. This second bone type is close to plexiform bone (Francillon-Vieillot et al. 1990). There are no LAGs in Dicraeosaurus, only irregularly spaced polish lines in some specimens. Dicraeosaurus thus grew in a similar way to Barosaurus type A, i.e. fast and without interruption.

Only one specimen of Janenschia, a large femur, was available for this study, preventing an assessment of variation. Janenschia shows some Haversian substitution as well as LAGs (Fig. 2). Secondary osteons are scattered throughout the cortex, decreasing in abundance towards the bone surface. Although the transition between cancellous bone of the medullary region and the cortex is well marked, as in Brachiosaurus and Barosaurus, there are large erosion cavities in the inner cortex (Fig. 2), as in Dicraeosaurus. The LAGs occur only in the outer fourth of the cortex. Growth in Janenschia thus seems to have been fast and uninterrupted at first but cyclical later in life.

A detailed growth record of the Janenschia femur is preserved in its numerous and well developed polish lines in the fibrolamellar bone and the lines of arrested growth in the lamellarzonal bone. Eleven widely spaced polish lines in the inner cortex are followed by 15 more closely spaced ones in the outer cortex. The thin outermost zone of lamellar-zonal bone preserves another 12 growth lines, developed as LAGs.

\section{Growth histories and life history}

By studying the primary bone of the cortex in more histologic detail, growth history can be interpreted in terms of life history. Based on ob- servations discussed in more detail elsewhere (Sander submitted), different types of fibrolamellar bone can be assigned to successive ontogenetic stages based on relative bone size, degree and pattern of vascularization, and organization of the bone matrix. Three ontogenetic types of fibrolamellar bone are distinguished in sauropod long bones: "hatchling bone", "juvenile bone", and "adult bone". Applying Amprino's law that a given bone type grows with the same rate irrespective of taxon or position in the skeleton (Ricqlès et al. 1991, Castanet et al. 1996), a qualitative estimate of life history parameters, such as size at sexual maturity, is possible. This is because the relative proportions of the three fibrolamellar bone types and the thin outer lamellarzonal bone in the cortex, correlated with bone size can be used to construct a qualitative growth curve for some of the Tendaguru sauropods (Fig. 3). Prerequisites are growth series of bones and/or large bones that preserve early through late ontogenetic stages in their cortex.

The sequence of four types of primary bone in the cortex was deposited at successively lower rates and translates into a qualitative growth curve that is characterized by three breaks marking abrupt decreases in growth rate (Fig. 3). These can safely be assumed to have been caused by some event in life history. The first decrease occurs in rather small, certainly juvenile individuals. Leaving the nest or termination of parental care come to mind as possibilities. Leaving the nest could lead to a decreased growth rate because of the increased mechanical loading

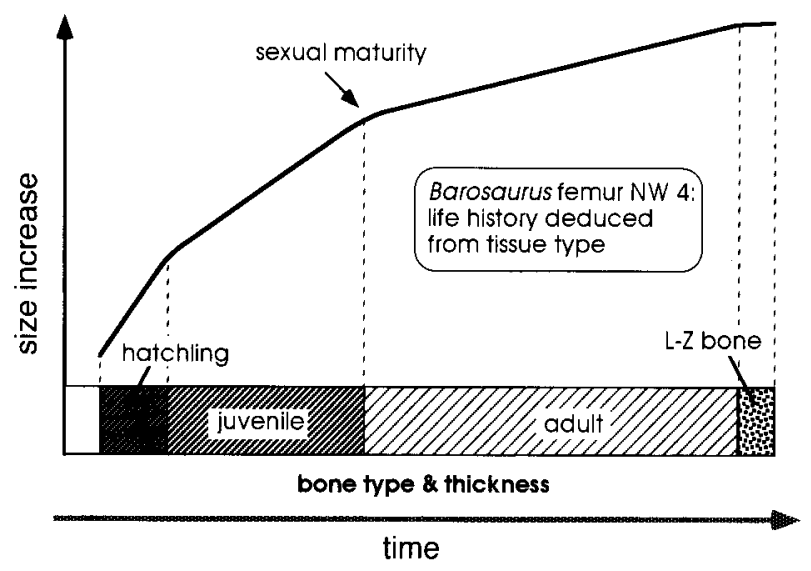

Fig. 3. Change of bone type during ontogeny in a single Barosaurus (type A) femur, specimen NW 4. This bone is exceptional in that nearly the entire life history of the individual is recorded in a single location of the cortex. The changes in tissue type record the stepwise decrease in growth rate. The second decrease is best interpreted as the onset of sexual maturity. Size increase can only be plotted qualitatively because the exact relationship between cortex thickness at any one time and bone size is unknown. 
of the skeleton. Leaving the nest could also lead to a decreased availability of food, as could the termination of parental care, leading to a decrease in growth rate.

The second break occurs in medium-sized individuals while the third break occurs only in large individuals and essentially records the cessation of growth. Sexual maturity most likely is marked by the second break. This is in accordance with the growth pattern seen in modern reptiles which reach sexual maturity well before maximum size. An alternative explanation for the second break, not involving auxilliary assumptions, is hard to find. One could argue that the second break just marks a slow down in growth as adult size is approached. However, this is inconsistent with the observation that the slow down occurs at between $40 \%$ and $70 \%$ of maximum size. One could also argue that there are intrinsic factors such as an absolute threshold body size, beyond which the deposition of "juvenile bone" could not be sustained. However, there is no positive evidence for this, nor are similar thresholds known in recent tetrapods. External environmental factors, such as a series of drought years, could explain a slow down in growth in single individuals but does not fit with the consistent occurrence of a slow down in small to medium-sized individuals of two unrelated species. Although uncommon among mam- mals, a pattern of prolonged growth at reduced rates after sexual maturity is also seen in the largest living terrestrial mammal, the male African elephant (Jarman 1983).

Size at sexual maturity can only be estimated with any confidence for Brachiosaurus and Barosaurus type A individuals, at about $40 \%$ and $70 \%$ maximum size, respectively (Fig. 4). The smallest Dicraeosaurus sampled was $80 \%$ maximum size and sexually mature (Fig. 4). Because of heavy remodelling and small sample size, no estimates are possible for Barosaurus type B.

The Janenschia femur, the only one of the species, was also sexually mature. It should be noted that the polish line record in this specimen is in accordance with the data derived from histologic bone type. It can be assumed that the polish lines in this specimen were deposited annually because they are regularly spaced and because growth lines are most commonly annual in living vertebrates (Castanet \& Smirina 1990, Castanet et al. 1993). In fact, in recent tetrapods regularly spaced growth lines in bone and dentin are very commonly used for aging, a technique called skeletochronology (for reviews, see Castanet \& Smirina 1990, Castanet et al. 1993, Klevezal 1996). Based on the polish line count, the individual of Janenschia sampled reached sexual maturity at 11 years, at well below maximum size. It continued to grow for another 15 years

\section{Life History Comparison}

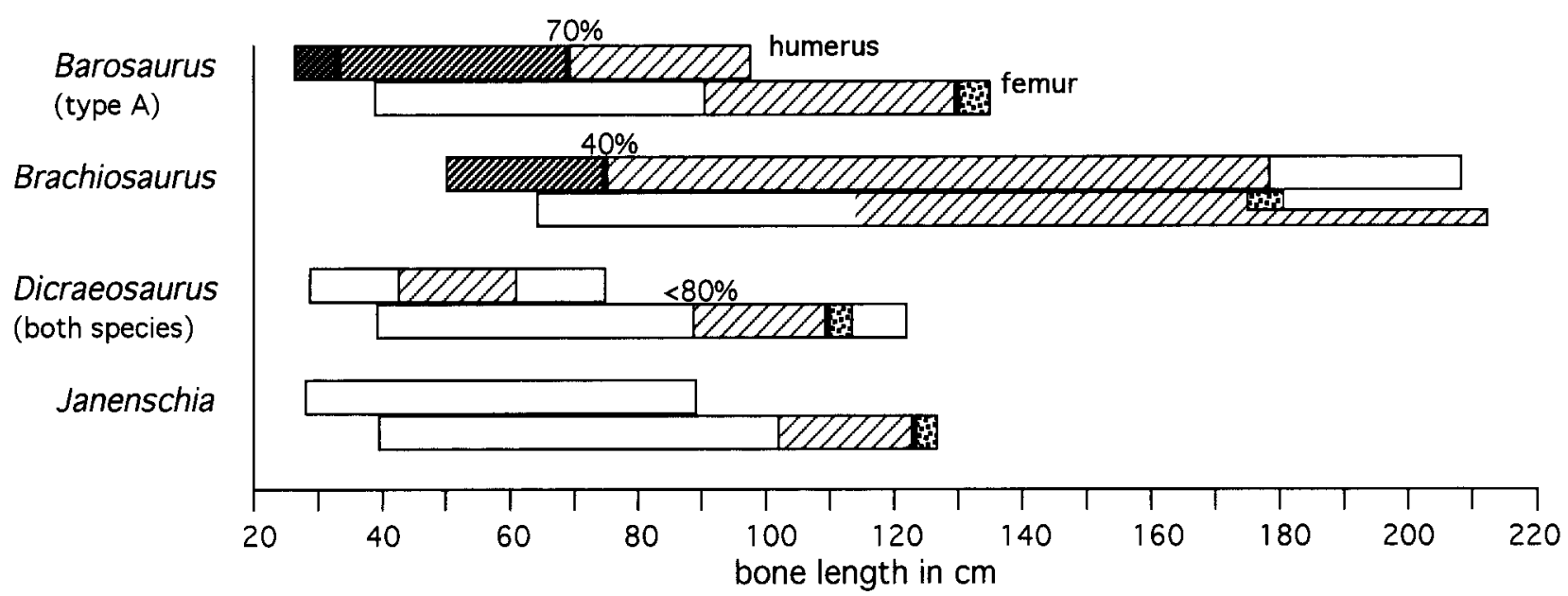

$\begin{array}{llll}\text { hatchling juvenile adult } & \mathrm{L}-\mathrm{Z} \text { bone } & \text { not sampled } \\ 2\end{array}$

Fig. 4. Comparison of the putative life history of all four Tendaguru sauropod genera bases on tissue type. The bar graphs for each genus are based on all available specimens. The percentage value is that of size at sexual maturity relative to maximum size. Intraspecific variation in life history can be observed in Brachiosaurus. Note that Barosaurus and Brachiosaurus reach sexual maturity at nearly the same size although maximum size differs greatly. Upper bar = humerus, lower bar = femur. $\mathrm{L}-\mathrm{Z}$ bone = lamellar-zonal bone. 
and lived until the age of 38 . However, it cannot be excluded that the innermost polish line was obliterated by remodelling and that one year is therefore missing from the record.

As noted above, growth came to a near standstill at the termination of fibrolamellar bone deposition. The thin outer layer of lamellar-zonal bone documents a minimal increase in bone circumference although growth in length may have been less than negligible. The deposition of lamellar-zonal bone did not mark the end of life because the one or more LAGs in the thin layer document a year to several years of life after maximum size was attained. Maximum size was apparently variable within species, as some large bones had still been growing at a fast rate at the time of death of the individual, while bones from other, smaller individuals record the cessation of growth (Fig. 4, Table 1). Although variable maximum size, a typical "reptilian" character, may seem inconsistent with mammalian growth rates, this mix of "reptilian" and "mammalian" features in bone histology is commonly observed in dinosaurs (Farlow et al. 1995).

\section{Discussion}

\section{Sexual dimorphism in Barosaurus bone?}

It is tempting to explain the differences between type A bone histology and type B bone histology of Barosaurus as related to sex. Type A could be interpreted as the male and type $\mathrm{B}$ as the female. In this scenario, fast growth in type A would be selected for in the male because of competition for mates. Females, on the other hand, would not face this selection pressure and could have afforded slower growth with interruptions. These interruptions could be related to the reproductive cycle. So could the heavy remodelling, considering the mineral storage function of bone. Phosphorus and calcium are both important components of the amniote egg, after all.

Coherent as this interpretations may seem, there are alternative explanation that need to be addressed, such taxonomic differences. Although the advantage of the simple morphology of sauropod long bones is their suitability for paleohistologic work, the disadvantage is their lack of diagnostic characters. It is conceivable that the Tendaguru assemblage contains not one but two diplodocid sauropods, the long bones of which are indistinguishable morphologically. One way to test the hypothesis of two diplodocids would be to search for further osteological evidence of two species in the Tendaguru collections. Another would be to study the histology of American Barosaurus long bones from the Morrison Formation. If they as well as the other Morrison diplodocids, Apatosaurus and Diplodocus, also showed two histologic types, sexual dimorphism would appear more likely than a taxonomic explanation.

Another explanation for the two bone types is that Barosaurus was strongly affected by environmental influences and that the current sample was taphonomically mixed, representing animals from different habitats or of slightly different geologic age. This hypothesis is contradicted by the absence of any dimorphism (or any kind of variations, for that matter) in Brachiosaurus and Dicraeosaurus, though they show no apparent differences in taphonomy from Barosaurus.

Also arguing against both the environmental influence and the two-taxa hypotheses is the case of the two different variants of Barosaurus recognized in the Tendaguru sample by Janensch (1961). He observed that there is a gracile variant from the Upper Intercalated Beds and a robust variant from the younger Upper Saurian Marl. The two variants both include type $A$ and type B histologies among them (Table 1).

\section{Causes of histologic differences among taxa}

The most unexpected result of this study was the great difference in histology between the taxa (Fig. 2). This was primarily evident in the degree and pattern of remodelling, but not so in the life history patterns. From what was previously known about sauropod bone histology (Ricqlès 1968, 1983, Rimblot-Baly et al. 1995, Reid 1981, 1990), the amount of variation in remodelling seen between the taxa would not have been greater than that expected among individuals of a single species. Only the controlled sampling (Fig. 1) revealed the uniformity of bone structure within a single species and the differences between taxa. But what does the variation in remodelling mean?

Remodelling unrelated to morphogenesis, especially the significance of Haversian systems, is incompletely understood at present (Francillon-Vieillot et al. 1990, Ricqlès et al. 1991). For Haversian systems, physiological factors such as rate of calcium and phosphorus metabolism or simple tissue age are probably significant as well as biomechanical factors. The latter have tradi- 
tionally played an important role in explaining the presence of Haversian bone in large tetrapods and mammals in particular (Ricqlès et al. 1991). In this study, a case could also be made for general correlation between body mass and degree of Haversian remodelling, because it is most important in the largest species, Brachiosaurus, and least in the smallest, Dicraeosaurus. This pattern is not followed by the type B individuals of Barosaurus, however, which show the greatest remodelling of any Tendaguru sauropod. With regard to the pattern of erosion activity, two groups appear to be present. One, in which erosion and remodelling proceeds from the medullary cavity outward, is represented by Barosaurus and Brachiosaurus (Fig. 2). The other, in which erosional activity extends deeply into cortex, is represented by Dicraeosaurus and $J a$ nenschia (Fig. 2). The significance of these differences is not clear at present.

Growth lines in fibrolamellar bone are also not evenly distributed among the Tendaguru taxa. While all show polish lines to varying degrees, lines of arrested grows (LAGs) only occur in Janenschia and Barosaurus type B (Fig. 2). As discussed earlier, their appearance might be related either to reproductive cycles or to environmental influence. In the case of Janenschia, seasonally induced cyclic growth appears to be the likely cause of the polish lines because they were already formed in the juvenile. The other taxa appear to have been less affected by seasonality because their growth line record is irregular, possibly due to a higher metabolic rate. This difference is in keeping with the plump and robust shape of the Janenschia bones (Janensch 1961) suggesting that the living animal was rather ponderous and may not have needed as high a metabolic rate as the other Tendaguru sauropods.

Another possibility is that Janenschia experienced marginal conditions in the Late Jurassic habitat of the Tendaguru region, precluding uninterrupted growth. This would be in accordance with the rarity of Janenschia in the assemblage. However, as only one specimen of Janenschia was studied, such conclusions are less well supported than for the other taxa. A possible refinement of these interpretations will come from sampling sauropods of the Morrison Formation because not only the same taxa occur in this formation as in the Tendaguru beds, but the Morrison covers a very large area with considerable environmental gradients (Dodson et al. 1980) which potentially could be reflected in bone histology.

\section{Comparison of life history strategies}

Although all Tendaguru sauropods show the same general pattern of considerable but determinate growth after sexual maturity, the obvious differences in life history strategies (Figs 2, 4) need to be dressed. Most notable and best documented is relative size at sexual maturity in Barosaurus type A (70\% maximum size) and Brachiosaurus (40\% maximum size). Compared to Barosaurus, Brachiosaurus reached its gigantic size by prolonging the phase of fast adult growth. A similar pattern was recently observed in the giant crocodilian Deinosuchus from the Late Cretaceous which did not have a higher growth rate than modern crocodilians, but retained relatively high growth rates much longer in life than recent crocodiles (Erickson \& Brochu 1999).

The life history strategy of early maturation observed in Brachiosaurus may, in fact, have been necessary to maintain viable populations. If both Brachiosaurus and Barosaurus grew roughly at the same rate as suggested by their bone microstructure, they reached sexual maturity at roughly the same age because their long bones were roughly of the same size at sexual maturity (Fig. 4). Because of the upper limit to age at sexual maturity of 20 years in sauropods (based on demographic simulations, Dunham et al. 1989), Brachiosaurus simply may have had to mature relatively earlier than Barosaurus to avoid this limit.

\section{Habitat partitioning and bone microstructure}

A characteristic feature especially of Late Jurassic sauropod assemblages is their diversity (Dodson 1990, McIntosh et al. 1997). To avoid interspecific competition, the species must have divided up the habitat by specializing in different ways, and this is consistent with the differences in size and body plan observed in the assemblages (Janensch 1961, Dodson 1990, McIntosh et al. 1997). In retrospect, differences in bone histology (Fig. 2) may thus appear less surprising, even if their correlation with life style is obscure at present.

\section{Future work}

In addition to sampling and studying the Morrison sauropods, other areas of research have to be pursued to arrive at an improved understand- 
ing of sauropod bone histology. As bone histology is always influenced by phylogenetic history as well as environmental factors, the early sauropods and particularly prosauropods as the ancestral stock or sistergroup of sauropods should be investigated. The well-known prosauropod Plateosaurus from the Upper Triassic of central Europe is a prime target for such work because of its abundance and preservation of growth series (Sander 1992).

Quantification of histology and comparison with modern analogs is an important next step to arrive at quantitative estimates of growth parameters; in other words, to take a quantitative approach to Amprino's Law. If bone deposition rate is known, either from comparison with recent animals in which it has been measured or from measuring the thickness of annual growth cycles in sauropods or other dinosaurs, the time it took to deposit a given thickness of primary cortex can be calculated and quantitative estimates of the age of the individual become possible. Such work on the sauropod Apatosaurus has been conducted by Curry (1998) and some data on living animals are slowly becoming available (Ricqlès et al. 1991, Castanet et al. 1996).

Comparison with recent large tetrapods is urgently needed to better understand the controlling factors for features such as Haversian substitution. Possibly polish lines will be detected in these recent forms as well, bringing us closer to an understanding of this very subtle record of variation in growth rate.

\section{Conclusions}

Bone histology reveals two important aspects of Tendaguru sauropods: first, apparently all Tendaguru sauropods combined the typically reptilian growth pattern of continued growth after sexual maturity and variable maximum size with typically mammalian growth rates. Second, differing histologies indicate that considerable variation within this life history framework was possible, in keeping with the rather different bauplan of the Tendaguru sauropod taxa and the different ecological niches they are likely to have occupied.

Studying growth and life history parameters in sauropods is not only an exciting endeavor driven by idle curiosity but also of some significance to the study of the physiology of modern vertebrates, simply because sauropod dinosaurs represent a size class lacking in today's terrestrial tetrapod faunas.

\section{Acknowledgements}

This research would have not been possible without the open mindedness of Wolf-Dieter Heinrich and Hans-Peter Schultze of the Museum für Naturkunde der Humboldt-Universität zu Berlin who gave me unprecedented opportunities to sample saurpod long bones for histologic work.

The paper benefitted greatly from discussions with Armand de Ricqlès (Université Paris VII) and Kristy Curry (State University of New York, Stony Brook), as well as members of the Tendaguru working group in Berlin. A thorough review of the manuscript by David Unwin is greatly appreciated.

The research was funded by a grant from the Deutsche Forschungsgemeinschaft (Sa 496/7-1) to the author.

\section{References}

Castanet, J., Francillon-Vieillot, H., Meunier, F. J. \& Ricqlès, A de 1993. Bone and individual aging. In Hall, B. K. (ed.). Bone, Volume 7: Bone growth - B: 145-283, CRC Press, Boca Raton.

Castanet, J., Grandin, A., Abourachid, A. \& Ricqlès, A. de 1996. Expression de la dynamique de croissance dans la structure de l'os périostique chez Anas platyrhynchos. Comptes Rendus de l'Academie des Sciences, Paris, Sciences de la vie 319: $301-308$.

Castanet, J. \& Smirina, E. 1990. Introduction to the skeletochronological method in amphibians and reptiles. - Annales des Sciences Naturelles, Zoologie, Paris, 13, Série 11: $191-196$.

Curry, K. 1998. Histological quantification of growth rates in Apatosaurus. - Journal of Vertebrate Paleontology 18: 36A.

Dodson, P. 1990. Sauropod paleoecology. In Weishampel, D. B., Dodson, P. \& Osmolska, H. (eds.). The dinosauria: 402-407, University of California Press, Berkeley.

Dodson, P., Behrensmeyer, A. K., Bakker, R. \& McIntosh, J. S. 1980. Taphonomy and paleoecology of the Upper Jurassic Morrison Formation. - Paleobiology 6: 208-232.

Dunham, A. E., Overall, K. L., Porter, W. P. \& Forster, C. A. 1989. Implication of ecological energetics and biophysical and developmental constraints for life-history variation in dinosaurs. In Farlow, J. (ed.). Paleobiology of the Dinosaurs. GSA Special Paper 238: 1-21, The Geological Society of America, Inc., Boulder.

Erickson, G. M. \& Brochu, C. A. 1999. How the "terror crocodile" grew so big. - Nature 398: 205-206.

Farlow, J. O., Dodson, P. \& Chinsamy, A. 1995. Dinosaur biology. - Annual Review of Ecology and Systematics 26: $445-471$.

Francillon-Vieillot, H., Buffrénil, V. d., Castanet, J., Gérardie, J., Meunier, F. J., Sire, J. Y., Zylberg, L. \& Ricqlès, A. de 1990. Microstructure and mineralization of vertebrate skeletal tissues. In Carter, J. G. (ed.). Skeletal Biomineralization: Patterns, Processes and Evolutionary Trends. Vol. 1: 471-530, Van Nostrand Reinhold, New York.

Janensch, W. 1961. Die Gliedmaßen und Gliedmaßengürtel der Sauropoden der Tendaguru-Schichten. - Paleontographica (Supplement) 7: 177-235.

Jarman, P. 1983. Mating systems and sexual dimorphism in large, terrestrial, mammalian herbivores. - Biological Reviews of the Cambridge Philosophical Society 58: $485-520$.

McIntosh, J. S., Brett-Surman, M. K. \& Farlow, J. O. 1997. Sauropods. In Farlow, J. O. \& Brett-Surman, M. K. (eds.) The Complete Dinosaur: 264-290, Indiana University Press, Bloomington and Indianapolis.

Reid, R. E. H. 1981. Lamellar-zonal bone with zones and annuli in the pelvis of a sauropod dinosaur. - Nature 292: $49-51$. 
- 1990. Zonal "growth rings" in dinosaurs. - Modern Geology 15: 19-48.

- 1997. How dinosaurs grew. In Farlow, J. O. \& Brett-Surman, M. K. (eds.). The Complete Dinosaur: 403-413, Indiana University Press, Bloomington and Indianapolis.

Ricqlès, A. de 1968. Recherches paléohistologiques sur les os longs des tétrapodes. - Quelques observations sur la structure des os longs des thériodontes. - Annales de Paléontologie 54: 3-15.

- 1983. Cyclical growth in the long limb bones of a sauropod dinosaur. - Acta Palaeontologica Polonica 28: $225-232$

Ricqlès, A. de, Meunier, F. J., Castanet, J. \& Francillon-Vieillot, H. 1991. Comparative microstructure of bone. In Hall, B. K. (ed.). Bone. Volume 3: Bone matrix and bone specific products: $1-78$, CRC Press, Boca Raton.

Rimblot-Baly, F., Ricqlès, A. de \& Zylberberg, L. 1995. Analyse paléohistologique d'une série de croissance partielle chez Lapparentosaurus madagascariensis (Jurassique moyen): Essai sur la dynamique de croissance d'un dinosaure sauropode. - Annales de Paléontologie (Invert.-Vert.) 81: 49-86.

Sander, P. M. 1992. The Norian Plateosaurus bonebeds of central Europe and their taphonomy. - Palaeogeography, Palaeoclimatology, Palaeoecology 93: 255-299.

- (submitted). Long bone histology of the Tendaguru sauropods: Implications for growth and development. - Paleobiology.

Varricchio, D. J. 1997. Growth and embryology. In Currie, P. J. \& Padian, K. (eds). Encyclopedia of Dinosaurs: 282-288, Academic Press, London.

Weishampel, D. B. \& Horner, J. R. 1994. Life history syndromes, heterochrony, and the evolution of Dinosauria. In Carpenter, K., Hirsch, K. F. \& Horner, J. R. (eds.). Dinosaur Eggs and Babies: 229-243, Cambridge University Press, New York. 